\title{
Searching for patent foramen ovale in a 44-year-old female patient after ischemic stroke - diagnostic problems
}

\author{
Małgorzata Zalewska-Adamiec ${ }^{1}$, Paweł Kralisz ${ }^{1}$, Hanna Bachórzewska-Gajewska ${ }^{1,2}$, Sławomir Dobrzycki ${ }^{1}$ \\ ${ }^{1}$ Department of Invasive Cardiology, Medical University of Bialystok, Poland \\ ${ }^{2}$ Department of Clinical Medicine, Medical University of Bialystok, Poland
}

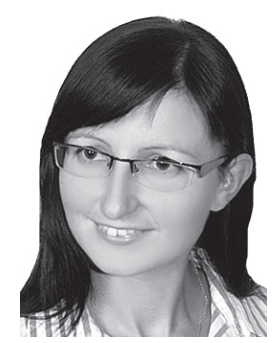

Kardiochirurgia i Torakochirurgia Polska 2016; 13 (2): 169-171

\begin{abstract}
Patent foramen ovale (PFO) is associated with the occurrence of cryptogenic strokes in young patients. Transesophageal echocardiography with contrast is the established standard in PFO diagnostics. We present the case of a 44-year-old female patient after ischemic stroke, in whom PFO was not detected by echocardiography; the defect was ultimately diagnosed by right heart catheterization.
\end{abstract}

Key words: patent foramen ovale, cryptogenic stroke.

\section{Introduction}

Patent foramen ovale (PFO) is observed in $25 \%$ of the general population; $46 \%$ of cryptogenic ischemic strokes are associated with its presence $[1,2]$. Diagnostic examinations focusing on PFO are recommended in all patients following a neurological incident before the age of 55 . The standard examination performed to detect or exclude PFO is transesophageal echocardiography (TEE) using contrast and the Valsalva maneuver $[3,4]$.

\section{Case report}

Following an ischemic stroke, the 44-year-old female patient was under out-patient observation for suspected PFO and was referred to the Department of Invasive Cardiology in order to undergo further diagnostics.

Eight months previously, the patient suffered from an ischemic stroke with right-sided hemiparesis and motor aphasia. At the time, computed tomography revealed a small hypodense focus (approx. $8 \mathrm{~mm}$ in diameter) in her white matter, on the left side, near the body of the lateral ventricle. No other abnormalities were found during ultrasonographic evaluation of the brain-supplying arteries and transthoracic echocardiographic (TTE) examination. During the hospitalization, the patient began motor reha-

\section{Streszczenie}

Drożny otwór owalny (patent foramen ovale - PFO) wiąże się z występowaniem udarów kryptogennych u młodych pacjentów. Przezprzełykowe badanie echokardiograficzne z kontrastem jest uznanym standardem w diagnostyce PFO. Przedstawiamy przypadek 44-letniej pacjentki po przebytym udarze niedokrwiennym mózgu, u której nie wykryto PFO w badaniu echokardiograficznym, natomiast wadę stwierdzono podczas cewnikowania prawego serca.

Słowa kluczowe: drożny otwór owalny, kryptogenny udar mózgu.

bilitation and speech therapy, which were continued on an out-patient basis after her discharge from the hospital. After several months, her neurological symptoms abated completely. The search for the causes of the stroke was continued in out-patient conditions. After excluding hematological disturbances (antiphospholipid syndrome, thrombophilia, hormonal contraception), PFO was considered to be the most likely suspect. The TEE with contrast and the Valsalva maneuver was performed, but the suspicion was not confirmed. Furthermore, the patient had never smoked cigarettes, and, apart from small varicose veins of the lower legs, no other cardiovascular risk factors were found. After the patient's medical history was analyzed at the Department of Invasive Cardiology, PFO appeared to be the most probable cause of the stroke. The patient was qualified for an invasive examination.

On admission to the clinic, the patient was in good general condition, arterial pressure: 131/94 mm Hg, in ECG: normal sinus rhythm (69 bpm), normal axis. Apart from small varicose veins of the lower legs and slight obesity (body mass index (BMI) $31 \mathrm{~kg} / \mathrm{m}^{2}$ ), physical examination revealed no neurological defects or other abnormalities. Similarly, no abnormalities were found by basic laboratory tests evaluating the patient's morphology (hemoglobin: $12.2 \mathrm{~g} / \mathrm{dl}$, erythrocytes: 4.41 million/ $\mu$ l, leukocytes:

Address for correspondence: Dr Małgorzata Zalewska-Adamiec, Department of Invasive Cardiology, Medical University of Bialystok, 24 A Skłodowskiej St, 15-276 Bialystok, Poland, phone: +48 8583184 96, e-mail: mzalewska5@wp.pl 


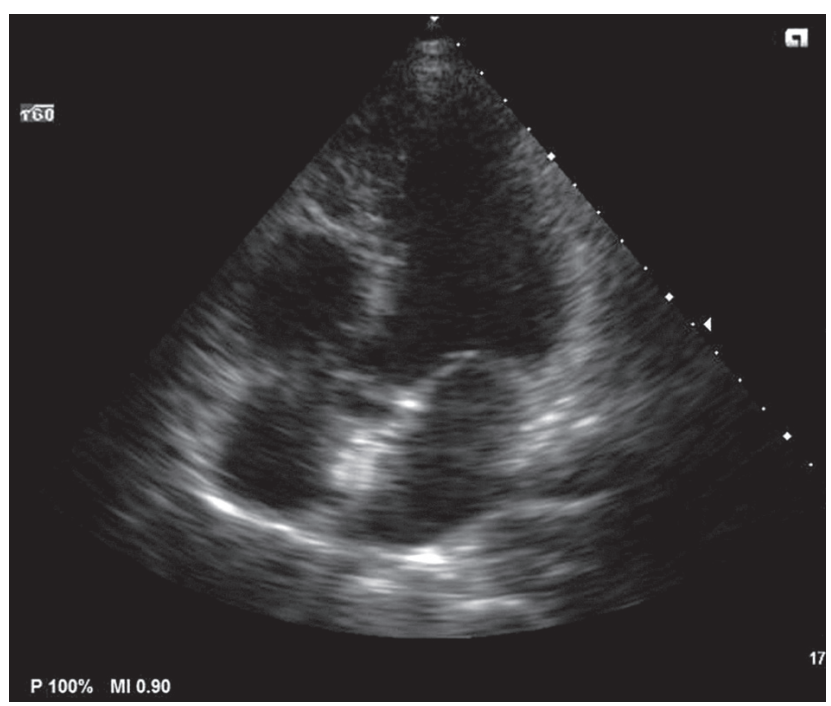

Fig. 1. Follow-up transthoracic echocardiography: the occluder at the level of the interatrial septum

7.63 thousand/ $\mu$ l, thrombocytes: 339 thousand/ $\mu l)$, coagulation system (fibrinogen: $371 \mathrm{mg} / \mathrm{dl}$, INR: 1.00, APTT: $26.7 \mathrm{~s}$ ), electrolytes (sodium: $138 \mathrm{mmol} / \mathrm{l}$, potassium: $4.36 \mathrm{mmol} / \mathrm{l}$ ), renal parameters (creatinine: $0.77 \mathrm{mg} / \mathrm{dl}$ ), hepatic parameters (alanine aminotransferase: $9 \mathrm{lU} / \mathrm{l}$ ), and lipid profile (total cholesterol: $171 \mathrm{mg} / \mathrm{dl}, \mathrm{LDL}: 121 \mathrm{mg} / \mathrm{dl}, \mathrm{HDL}$ : $49 \mathrm{mg} / \mathrm{dl}$, triglycerides: $67 \mathrm{mg} / \mathrm{dl}$ ).

On the $2^{\text {nd }}$ day of hospitalization, a multipurpose catheter was introduced into the patient's right atrium through the femoral vein under intravenous analgosedation (midazolam) and TEE control. Subsequently, the catheter was directed through the interatrial septum into the left atrium, demonstrating the presence of a PFO. Concurrently, the defect in the atrial septum was successfully closed through the percutaneous implantation of an Amplatz system (Amplatzer PFO Occluder, St. Jude Medical) with the diameter of both discs equal to $18 \mathrm{~mm}$. The position of the occluder and the lack of leakage at its level were verified using echocardiography, and the system was released. Perioperatively, the patient received $2 \mathrm{~g}$ of intravenous ampicillin, $600 \mathrm{mg}$ of clopidogrel, and $300 \mathrm{mg}$ of acetylsalicylic acid (ASA).

The perioperative period and further hospitalization were uneventful; in terms of pharmacotherapy, the double antiplatelet therapy was continued (clopidogrel $75 \mathrm{mg} /$ day and ASA $75 \mathrm{mg} /$ day).

On the $2^{\text {nd }}$ postoperative day, follow-up TTE was performed, confirming proper occluder position and no signs of leakage within the interatrial septum (Fig. 1). The patient was discharged home in good general condition; she was advised to take her medication regularly (clopidogrel $75 \mathrm{mg} /$ day for 3 months, ASA $75 \mathrm{mg} /$ day for 6 months, and pantoprazole $20 \mathrm{mg} /$ day during clopidogrel use) and to continue infective endocarditis prophylaxis for 6 months after the procedure.

Three months after the procedure, the patient reported to the clinic for a follow-up echocardiographic examination. The patient feels well and does not raise any complaints.
The TTE demonstrated that the occluder remains in the proper position at the level of the interatrial septum without signs of leakage.

\section{Discussion}

A PFO results from the lack of anatomical closure which should normally take place soon after birth; the closure, however, may be only functional. In this case, it may become patent under particular circumstances, e.g., during a Valsalva maneuver or due to significant atrial dilatation. The PFO occurs in $25 \%$ of the general population and has a tendency to grow with each decade of life. When the pressure in the right atrium is higher than in the left, a right-to-left shunt may develop through the PFO. Shunting through a PFO promotes the development of paradoxical embolisms (with embolic material from systemic veins moving into the arterial system), which may cause cryptogenic strokes, constituting $40 \%$ of strokes in individuals below the age of $55[1-3,5,6]$.

Recommendations of American cardiological and neurological associations consider contrast TEE with Valsalva to be the first and only method of PFO diagnostics. The standards recommend the performance of transesophageal echocardiography in all stroke patients below the age of 55 in order to exclude PFO [7, 8]. Although TEE is characterized by very high sensitivity in PFO diagnostics, false negative results are obtained in a small percentage of patients [9]. Van et al. assessed the sensitivity of TEE with Valsalva in 38 patients after neurological incidents with confirmed PFOs, who were qualified for percutaneous defect closure. Transcranial Doppler (TCD) was used to verify the findings. In $7.9 \%$ of the patients, the results were false negative, which was explained by significant discomfort associated with the transesophageal probe during the Valsalva maneuver and by insufficient pressure gradients between the right and left atrium [10].

Our clinic cooperates closely with neurological departments, which refer patients with PFO and patients after (probably cryptogenic) strokes to our clinic in order to extend the diagnostics and qualify the patients for percutaneous PFO closure. As our center lacks experience with transcranial ultrasonography, each patient undergoes TEE with contrast and Valsalva.

In the described patient, a cryptogenic stroke was diagnosed after all other causes of the cerebral incident were excluded. Transesophageal echocardiography did not reveal the presence of a PFO. However, taking into account the patient's young age, responsible occupation (school principal), and engagement in rehabilitation and the diagnostic process, as well as the possibility of a false negative TEE result, a decision was made to verify the examination using right heart catheterization, which confirmed the presence of PFO. Considering the patient's preference concerning treatment, concurrent percutaneous closure of the PFO was performed.

The heretofore published recommendations concerning secondary prevention of stroke in PFO patients are signifi- 
cantly limited by the lack of unambiguous data from randomized studies [11-16]. American cardiological and neurological associations recommend the use of antiplatelet agents in PFO patients after stroke or transient ischemic attack (TIA) to prevent repeated cerebral incidents (class Ila, level B). The use of oral anticoagulants (class IIb, level B) and percutaneous PFO closure (class IIB, level C) can also be considered to prevent repeated neurological incidents [17]. Although advantages of percutaneous PFO closure over pharmacological treatment in the prevention of repeated strokes have not yet been demonstrated, surgical treatment is undoubtedly an attractive and often preferred alternative for young patients who wish to avoid the burdensome anticoagulative treatment. Many centers using this procedure, including our clinic, perform percutaneous PFO closures in patients as soon as after the first cerebral incident $[18,19]$.

After the successful detection of PFO during right heart catheterization in the described patient, we will consider invasive diagnostics in each patient with high probability of prior cryptogenic stroke in whom TEE fails to confirm the presence of PFO.

\section{Disclosure}

Authors report no conflict of interest.

\section{References}

1. Hausmann D, Mügge A, Becht I, Daniel WG. Diagnosis of patent foramen ovale by transesophageal echocardiography and association with cerebral and peripheral embolic events. Am J Cardiol 1992; 70: 668-672.

2. Alsheikh-Ali AA, Thaler DE, Kent DM. Patent foramen ovale in cryptogenic stroke: incidental or pathogenic? Stroke 2009; 40: 2349-2355.

3. Fisher DC, Fisher EA, Budd JH, Rosen SE, Goldman ME. The incidence of patent foramen ovale in 1,000 consecutive patients. A contrast transesophageal echocardiography study. Chest 1995; 107: 1504-1509.

4. Knebel F, Masuhr F, von Hausen W, Walde T, Dreger H, Raab V, Yuerek M, Baumann G, Borges AC. Transesophageal echocardiography in patients with cryptogenic cerebral ischemia. Cardiovasc Ultrasound 2009; 7: 15.

5. Łukasik M, Kozubski W. Udar kryptogenny - drożny otwór owalny - migrena z aurą: przypadkowa triada czy związek przyczynowo-skutkowy? Część I. Neurol Neurochir Pol 2012; 46: 161-168.

6. Larrue V, Berhoune N, Massabuau P, Calviere L, Raposo N, Viguier A, Nasr N. Etiologic investigation of ischemic stroke in young adults. Neurology 2011; 76: 1983-1988.
7. ACC/AHA/ASE 2003 Guideline Update for the Clinical Application of Echocardiography: Summary Article: A Report of the American College of Cardiology/American Heart Association Task Force on Practice Guidelines (ACC/AHA/ ASE Committee to Update the 1997 Guidelines for the Clinical Application of Echocardiography). Circulation 2003; 108: 1146-1162.

8. Messé SR, Silverman IE, Kizer JR, Homma S, Zahn C, Gronseth G, Kasner SE; Quality Standards Subcommittee of the American Academy of Neurology. Practice parameter: recurrent stroke with patent foramen ovale and atrial septal aneurysm: Report of the Quality Standards Subcommittee of the American Academy of Neurology. Neurology 2004; 62: 1042-1050.

9. Schneider B, Zienkiewicz T, Jansen V, Hofmann T, Noltenius H, Meinertz T. Diagnosis of patent foramen ovale by transesophageal echocardiography and correlation with autopsy findings. Am J Cardiol 1996; 77: 1202-1209.

10. Van H, Poommipanit P, Shalaby M, Gevorgyan R, Tseng CH, Tobis J. Sensitivity of transcranial Doppler versus intracardiac echocardiography in the detection of right-to-left shunt. JACC Cardiovasc Imaging 2010; 3: 343-348.

11. Homma S, Sacco RL, Di Tullio MR, Sciacca RR, Mohr JP. Effect of medical treatment in stroke patients with patent foramen ovale: patent foramen ovale in Cryptogenic Stroke Study. Circulation 2002; 105: 2625-2631.

12. Casaubon L, McLaughlin P, Webb G, Yeo E, Merker D, Jaigobin C. Recurrent stroke/TIA in cryptogenic stroke patients with patent foramen ovale. Can J Neurol Sci 2007; 34: 74-80.

13. Orgera MA, O'Malley PG, Taylor AJ. Secondary prevention of cerebral ischemia in patent foramen ovale: systematic review and meta-analysis. Southern Med J 2001; 94: 699-701.

14. Ntaios G, Papavasileiou V, Makaritsis K, Michel P. PFO closure vs. medical therapy in cryptogenic stroke or transient ischemic attack: a systematic review and meta-analysis. Int J Cardiol 2013; 169: 101-105.

15. Riaz IB, Dhoble A, Mizyed A, Hsu CH, Husnain M, Lee JZ, Lotun K, Lee KS. Transcatheter patent foramen ovale closure versus medical therapy for cryptogenic stroke: a meta-analysis of randomized clinical trials. BMC Cardiovasc Disord 2013; 13: 116.

16. Hernandez J, Moreno R. Percutaneous closure of patent foramen ovale: "closed" door after the last randomized trials? World J Cardiol 2014; 6: 1-3.

17. Furie KL, Kasner SE, Adams RJ, Albers GW, Bush RL, Fagan SC, Halperin JL, Johnston SC, Katzan I, Kernan WN, Mitchell PH, Ovbiagele B, Palesch YY, Sacco RL, Schwamm LH, Wassertheil-Smoller S, Turan TN, Wentworth D; American Heart Association Stroke Council, Council on Cardiovascular Nursing, Council on Clinical Cardiology, and Interdisciplinary Council on Quality of Care and Outcomes Research. Guidelines for the prevention of stroke in patients with stroke or transient ischemic attack: a guideline for healthcare professionals from the American Heart Association/American Stroke Association. Stroke 2011; 42: 227-276.

18. Rzezak J, Sypuła S, Pawłowski T, Gołębiewski S, Kwiatkowski P, Śliwiński Z, Kulawik T, Vassilev D, Gil RJ. Przezskórne zamykanie ubytków międzyprzedsionkowych i przetrwałych otworów owalnych zapinką Amplatza w znieczuleniu miejscowym - doświadczenia pojedynczego ośrodka. Post Kardiol Interw 2008; 4: 55-60.

19. Windecker S, Meier B. Patent foramen ovale and cryptogenic stroke: to close or not close? Circulation 2008; 118: 1989-1998. 